The Society for the Promotion of Hellenic Studies was founded in 1879 to advance the study of Greek language, literature, history, art and archaeology in the ancient, Byzantine and modern periods. Membership is open to all and there is a reduced rate for students.

\section{MEMBERSHIP RATES}

Rates are as follows: full members $£ 58, £ 57$ for those who pay by direct debit; student associates $£ 25$; corporate members $£ 225$. Life membership is available at $£ 580$ to those over 65 years of age after five years' full membership. Institutional subscriptions are available from Cambridge University Press. Please consult the Society's website for further details (hellenicsociety.org.uk).

\section{PUBLICATIONS}

The Journal of Hellenic Studies is published annually and sent to all members of the Society. Members may choose to receive Archaeological Reports or $A R G O$ (a bi-annual magazine, first published in 2015) or to top up their subscription to receive all three publications.

\section{THE JOINT LIBRARY}

The Society helps to maintain the Joint Library in conjunction with the Roman Society and the Institute of Classical Studies. Membership of the Hellenic Society allows the reader to borrow (within the UK) up to four books at a time, either in person or by post.

\section{LECTURES}

The Society arranges an annual lecture series in London, and helps to arrange other lectures in collaboration with the various local branches of the Classical Association: a programme of all these lectures is circulated in September to UK members and is posted on the website. A selection of past lectures can be viewed on the Society's YouTube channel (youtube.com/user/HellenicSociety1879).

\section{GRANTS}

The Society aims to help those engaged in Hellenic studies at all levels, and to this end it makes grants of various kinds (further details and application forms are available from the website).

- Schools teaching Greek language, history or civilization may apply for grants: generous donations from the A.G. Leventis Foundation have recently enabled the Society to increase the grants awarded, in number and size.

- Postgraduate students and other scholars engaged in specific areas of research may apply for grants from the Dover Fund.

- Institutions (typically, but not exclusively, universities) may apply for a grant from the Council of the Society, to fund academic conferences and other events.

\section{CONTRIBUTIONS TO THE JOURNAL}

Contributions should be anonymized and sent, preferably electronically, to the Editor douglas.cairns@ed.ac.uk or to Professor Douglas Cairns, School of History, Classics and Archaeology, University of Edinburgh, William Robertson Wing, Old Medical School, Teviot Place, Edinburgh EH8 9AG.

A style guide and further information on submission of copy and illustrations are available on the Society's website. Books for review should be addressed to the Librarian at the Society address. The Journal does not accept unsolicited book reviews. 
Cambridge Core

For further information about this journal please go to the journal web site at

cambridge.org/jhs
CAMBRIDGE UNIVERSITY PRESS 